\title{
A Critical Examination of Breeders' Monopoly Rights to the Detriment of Farmers' Rights Under the Ethiopian Plant Breeders' Rights Law
}

\author{
Temesgen Abebe Degu \\ Wachemo University, School of Law, Hosaena, ETHIOPIA
}

Received: 20 January 2021 - Accepted: 4 April 2021 • Published Online: 1 June 2021

\begin{abstract}
Ethiopia adopted plant breeders' rights proclamation in 2006 to provide recognition and economic reward for breeders for their effort and investment so as to encourage their involvement in the sector. At the same time, the proclamation aims to ensure that the farming and pastoral communities of Ethiopia, who have been conserving and continue to do so in the future the agro-biodiversity resource used to develop new plant varieties, continue to their centuries old customary practice of use and exchange of seed. This article aims at investigating the extent to which the proclamation accommodates its stated objective by giving adequate recognition to farmers' rights. The investigation adopts a qualitative method by analyzing both primary materials and secondary sources. The article concludes that the Ethiopian plant breeders' rights proclamation fails to adequately incorporate farmers' rights beyond its preamble.
\end{abstract}

Keywords: breeders' rights, farmers' rights, IPRs, monopoly rights, patent.

\section{Introduction}

Agricultural innovations have for long remained outside the domain of intellectual property rights (IPRs) owing to ethical and socioeconomic reasons. With the advent of modern agro-biotechnology, however, the sector began to be subjected to IPRs. Today, newly developed plant varieties are protected in some form of IPRs. Particularly, the TRIPPS agreement provides that plant varieties (PVP) shall be protected either through patent or an effective sui generis system, or a combination of the two. In this direction, Ethiopia adopted plant breeders' rights (PBRs) law for the first time in 2006. This proclamation mainly accords breeders of new plant varieties certain monopoly rights akin to patent. Even if the proclamation recognizes farmers' role in maintaining genetic diversity and conservation, it only paid one provision for farmers' exemption to use and exchange farm saved seeds. This article aims at evaluating the appropriateness of granting monopoly rights for private breeders with little attention to farmers' rights on the basis of various ethical and socioeconomic reasons.

The article, in terms of organization, consists of seven sections. While the first section is devoted for the introduction, the second section deals with the introduction of IPRs in the agricultural sector. Section three discusses plant variety protection (PVP) under the TRIPS agreement, along with the degree of flexibility available to members in designing the same. After a brief introduction of the Ethiopian PBRs law in section four, the pros and cons of PVP will be

(C) Authors. Terms and conditions of Creative Commons Attribution 4.0 International (CC BY 4.0) apply. Correspondence: Temesgen Abebe Degu, Wachemo University, School of Law, Hosaena, ETHIOPIA. Email: timatimdegu@yahoo.com. 
addressed under section five. Section six evaluates the extent of place given for farmers' rights under the Ethiopian PBRs law. Finally, the last section concludes the article.

2. The introduction of intellectual property rights (IPRs) in the agricultural sector

The agricultural sector had for long been exempted from the purview of intellectual property rights such as patent that grant monopoly rights to a private individual. ${ }^{1}$ Granting intellectual property rights to an individual over life forms is equivalent to making mankind own nature which is very unacceptable from both ethical and religious perspectives. Agrobiotechnology, therefore, raises a number of ethical issues revolving around mans' interference with God and nature, respect for sacredness of nature, and ownership of life forms. ${ }^{2}$ Patenting or the exclusive appropriation of life forms also contravenes human rights to life. This is so because the very existence of humankind is founded upon life forms. ${ }^{3}$

Intellectual property rights (IPRs) steadily began to make its way in to agricultural sector with the introduction of plant breeders' rights (PBRs') modeled on patent and the patenting of life forms in many developed countries. ${ }^{4}$ IPRs in the form of sui generis system were for the first time extended to the agro-biological field in the United States under the 1930 US Plant Patent Act. A sui generis system (its own kind of protection) was designed because it was problematic to accord patent for plant varieties (PVP). Breeding activity simply involves discovery of genes that exist naturally. It is difficult to show novelty, inventive step, and produce written description of the invention in standard breeding activities as is the case with patentable inventions. ${ }^{5}$ Protection was, however, given for breeders after analogizing biotechnological inventions with mechanical inventions which, in effect, blurred the demarcation between organisms and manufacture. ${ }^{6}$ Though plants are products of nature, breeders were awarded for their artificial selection and reproduction of what exists in nature by reshuffling the concept of origination into discovery. The fact that "mechanical inventors are inventors at the beginning, and breeders are inventors after the fact" means that invention "became an inductive rather than originating act". 7 Furthermore, the requirement of written specification of was loosened owing to the incapability to reproduce plant innovations in writing unlike manufactures.

${ }^{1}$ Philippe Cullet (2001). Plant variety protection in Africa: Towards compliance with the TRIPS Agreement. Journal of African law, 45(I), 97, p. 109.

2 Jonathan Robinson (1999). Ethics and transgenic crops: A review. Electronic Journal of Biotechnology, 2(2), 71, pp. 71 \& 76-78.

3 African model legislation for the protection of the rights of local communities, farmers and breeders, and for the regulation of access to biological resources (2000). OAU, Algeria, Preamble, par. 9 \& art. 9(1).

4 Philippe Cullet (2003). Food security and intellectual property rights in developing countries. IELRC Working paper 2003-3, International Environmental Law Research Center, Geneva, p. 8.

5 Michael Blakeney (2007). Plant variety protection, international agricultural research, and exchange of germplasm. Legal aspects of sui generic and patent regimes. In A Krattiger et al. (Eds.), Intellectual property management in health and agricultural innovation: A handbook of best practices. MI H R, Oxford, pp. $401 \& 407$.

6 Allan Pottage and Brand Sherman (2007). Organisms and manufactures: On the history of plant inventions. Melbourne University Journal, 31(2), 539, pp. 543-44.

7 Id at pp. 554-55, 558-59, \& 561-65. 
Nowadays, particularly with the adoption of the UPOV and TRIPS, intellectual property rights to breeders are a well-established system in many countries including developing nations.

3. Plant variety protection under the TRIPS Agreement and the sui generis option

Presently, agro-biological innovation is one field of activity that is subject to IPRs at the international level following the TRIPs agreement. It was the industrial associations of the West that stood behind the inclusion of agricultural innovations under the international regulatory regime. ${ }^{8}$ Even if the TRIPs agreement exempts members from patenting plants and animals other than micro-organisms, and essentially biological processes, it still requires protection for plant varieties. According to the agreement, members are bound to give protection for plant varieties "either by patent or sui generis system or a combination thereof" ${ }^{9}$

The sui generis option under the TRIPS agreement, arguably, gives sufficient flexibility for developing countries to tailor make their own PVP laws in tune with their national interests rather than adopting monopoly rights like patent. ${ }^{10}$ The TRIPs Agreement, for one thing, does not define what constitutes plant variety for the purpose of protection. Nor does it require the adoption of PVP laws parallel with the stronger Agreements for the Protection of New Varieties of Plants such as the UPOV. So, it is up to each countries choice to define what constitutes protectable plant varieties and the nature of right to be granted. Notwithstanding the claim that the sui generis option under the TRIPS Agreement implicitly requires the adoption of UPOV, ${ }^{11}$ there is no binding obligation, in this regard, since none of the UPOV Conventions is referred to under TRIPS Agreement. ${ }^{12}$ From this, it can be argued that countries retain considerable flexibility in designing their plant variety protection law although they often fail so to do in practice.

The problem, however, is that whatever the kind of sui generis system of protection countries might adopt; it must be effective for it to comply with the TRIPS agreement. Though the TRIPS Agreement does not define what constitutes an effective sui generis system, it can be understood from various provisions of the agreement that it should encompass the following requirements. First, it has to accord protection to all kinds of plant varieties in the form of IPRs, i.e exclusive rights and/or remuneration regarding the exploitation of protected varieties. ${ }^{13}$ The provision dealing with sui generis system falls under one of the sections of TRIPS Agreement which is the subject of article 1(2) requiring the application of IPRs. This means a kind of protection in the form of monopoly property rights should be accorded to all plant species and genera. ${ }^{14}$ In addition to this, any sui generis system should provide for an effective enforcement

8 Michael Blakeney (2007). Supra note 5, p. 402.

9 Agreement on Trade Related Aspects of Intellectual Property Rights (TRIPS) (1994). Marrakesh Agreement Establishing the World Trade Organization, Annex 1C, 1869, U.N.T.S. 229, 33 L.L.M. 1997, WTO, Art. 27(3)(b).

${ }^{10}$ Michael Blakeney (2007). Supra note 5, p. 413.

${ }^{11}$ Calestous Juma (1999). Intellectual property rights and globalization: Implications for developing countries. Science, Technology and Innovation Discussion Paper No. 4, Center for International Development, Harvard University, Cambridge, p. 9.

${ }_{12}$ Dan Leskien and Michael Flitner (1997). Intellectual property rights and plant genetic resources. Options for a sui generis system. Issues in Genetic Resources No. 6, International Plant Genetic Resources Institute, Italy, p. 27; and Philippe Cullet (2001). Supra note 1, pp. 100-103.

13 Michael Blakeney (2007). Supra note 5, p. 412.

14 Dan Leskien and Michael Flitner (1997). Supra note 12, p. 27-8. 
mechanism, and comply with the principles of national treatment, and most-favored-nation treatment. ${ }^{5}$

From this, it can be strongly argued that member countries do not have as much sufficient flexibility as it might appear in designing their own system of law. Indeed, many developing countries even have taken the stronger UPOV system as a model in designing their national laws in an effort to meeting the requirement of an effective sui generis system of protection under the TRIPs. ${ }^{16}$ This is the case due to strong pressure from the developed world which developing countries often find it hard to withstand. We must not, however, forget some countries that have managed to design their own sui generis system against all odds. ${ }^{17}$

\section{Plant breeders' rights (PBRs) in Ethiopia}

In 2006, Ethiopia adopted plant breeders' rights (PBRs') proclamation which was derived from the OAU model law. ${ }^{18}$ The sui generis system under the OAU model law is, in turn, based on the UPOV, especially the one adopted in $1991 .{ }^{19}$ For instance, the nature of breeders' rights and the duration thereof under the model law is parallel to the UPOV. ${ }^{20}$ There is therefore a tendency, even if indirect, that the Ethiopian plant breeders' law is influenced by the UPOV system that provides for stronger protection to breeders' even if Ethiopia is not a party to the convention.

The stated objective of the Ethiopian PBRs' proclamation is to incentivize investment in new plant varieties with the view to improving agricultural development. ${ }^{21}$ According to the proclamation, plant varieties are worth protection if they are new, ${ }^{22}$ distinct, stable and homogenous. ${ }^{23}$ Having satisfied these criterions, plant breeders will have an exclusive right to sell, license and produce the seed or propagating material of protected varieties, ${ }^{24}$ generally for 20 to 25 years. ${ }^{25}$ As can be seen here both the nature of plant breeders' rights and its duration resembles that of patent in strength and duration. Any unauthorized use of a protected variety constitutes an

15 Agreement on Trade-Related Aspects of Intellectual Property Rights (TRIPS) (1994). Supra note 9, Arts. $3,4 \& 41(1)$.

16 Philippe Cullet (2001). Supra note 1, p. 100.

${ }_{17}$ Phil Thorpe (2002). Study on the implementation of the TRIPS Agreement by developing countries. Study Paper 7, Commission on Intellectual Property Rights, p. 25.

18 Philippe Cullet (2001). Supra note 1, p. 100.

19 Michael Blakeney (2007). Supra note 5, p. 417.

${ }_{20}$ Philippe Cullet (2001). Supra note 1, p. 104. [cf. International Convention for the Protection of New Varieties of Plants (UPOV), (1978), Paris 2 December 196, as Revised at Geneva on November 10, 1972, and on October 23, 1978, UPOV Doc., Arts. 2, 5 \& 8; and International Convention for the Protection of New Varieties of Plants (UPOV), (1978), Paris 2 December 196, as Revised at Geneva on 19 March 1991, UPOV Doc. 221(E), 1996, Arts. 3, 5, 14 \& 19.].

${ }^{21}$ Plant Breeders' Rights Proclamation (2006), Proclamation No. 481/2006, Federal Negarit Gazette, $12^{\text {'h }}$ Year No. 12, Addis Ababa, Ethiopia, Preamble, par. 1-3.

22 Id at Arts. 3(1) \&14(1).

23 Id at Arts. 2(5)(a), (b) \& (c).

24 Id at Arts. 5(1) \& (2).

25 Id at Art. 9. 
infringement and entails serious penalty under the law. ${ }^{26}$ There are, though, few instances of exemptions and restrictions of PBRs' upon limited grounds provided for in the proclamation. ${ }^{27}$

The plant breeders' proclamation, in addition, aims at ensuring farmers to keep on using their customary seed use and exchange practices in view of their contribution to preserving agro-biodiversity. ${ }^{28}$ Farmers are entitled to save, use, exchange and sell farm-saved seed or propagating material of both farmers' varieties and protected varieties. ${ }^{29}$ But as for using protected varieties, farmers are allowed to use it only for noncommercial purposes, or they should be certified. $3^{3}$ Farmers' right to use and exchange farm saved seed is only one component of the broader aspects of farmers' rights. Farmers' rights broadly consist of the rights to protection of farmers' traditional knowledge including protection of farmers' varieties, the right to equitable share benefits, and the right to participate in decision making. Unlike the breeders' rights sections, the proclamation comes to be somewhat loose when it comes to farmers' rights.

As a matter of principle at least, PBRs' is not different from the conventional monopoly rights such as patent in terms of its nature and duration. ${ }^{31}$ The issue, then, is what is the benefit and cost of such kind of law in general and interplay between breeders and farmers rights in particular. This is briefly dealt with in the next section.

\section{Arguments for and against plant variety protection (PVP)}

It is said that IPRs offer a strong incentive to attract private investment in agrobiotechnological improvements. It motivates breeders to invest in new and improved plant varieties by assuring that they will recover the cost of their innovation..$^{2}$ This, in turn, leads to the release of new, high yielding, and disease resistant plant varieties that eventually contributes to agricultural development. 33 The TRIPS Agreement provides, in this regard, that "the underlying public policy objectives of national systems for the protection of intellectual property include developmental and technological progress". 34

There is, none the less, no conclusive evidence so far about the role of IPRs in encouraging private engagement in plant breeding activities. Historically, private breeding industries flourished in the absence of PVP both in the North and South. ${ }^{35}$ So, granting an

${ }^{26}$ Id at Arts. 5(2), 24 \& 29.

27 Id at Arts. 6 \& 7.

${ }^{28}$ Id at Preamble, par. 4.

29 Id at Arts. 28(1)(a) \& (c). [cf. The Protection of Plant Varieties and Farmers' Rights Act (2001), No. 53/2001, Gazette ofIndia, Extraorodinary Part II-Section 1, Ministry of Law, Justice and Company Affairs, India, Art.39(1)(iv).

30 Id at Art. 6. [also, Seed Proclamation (2000), Proclamation No. 206/200o, Federal Negarit Gazette, 6" Year No. 36, Addis Ababa, Ethiopia, Art. 3.

${ }^{31}$ Philippe Cullet (2001). Supra note 1, p. 109.

${ }^{32}$ Neil D. Hamilton (2001). Legal issues shaping society's acceptance of biotechnology and genetically modified organisms. Drake Journal of Agricultural Law, 6(1), 81, p. 88.

33 Sachin Chaturvedi (2002). Agricultural biotechnology and new trends in IPRs regime: Challenges before developing countries. Economic \& Political Weekly, 37(13), 1212, p. 1213.

34 Agreement on Trade-Related Aspects of Intellectual Property Rights (TRIPS) (1994). Supra note 9, preamble par. 5 .

35 Philippe Cullet (2001). Supra note 1, pp. 355-56. 
intellectual property rights is not necessarily an incentive for breeders. Though granting temporary monopoly rights for inventors is said to enhance socioeconomic development, 36 they do not, however, fit with the conventional agricultural management practices because the latter depends and promotes different knowledge, and identifies and rewards innovations in a different way than the former. 37 Traditional agricultural management practices do not exclusively rely on financial schemes as opposed to monopoly rights.

Contrary to laboratory generated knowledge, farmers' knowledge is lessindividualistic in that it involves the contributions of different individuals thereto. Granting monopoly rights to a single inventor not only, therefore undermines the contributions of other individuals but also impedes the free accessibility of inventions. ${ }^{38}$ The agricultural system of developing countries, particularly sub-Saharan Africa, significantly relies on farmers' varieties and free exchange of germplasm. Conversely, the use of commercial varieties is very limited in the continent. 39 In Ethiopia, for instance, farmers' varieties account for $94 \%$ of germplasm..$^{40}$ It follows that there seems to be little justification in championing private breeders' rights over farmers' rights.

It is also inappropriate to commercialize the agricultural sector because of its key significance for the economy of developing countries. Unlike the West, agriculture is a key sector in Africa, particularly in Sub-Sahara, that constitutes the livelihood of the majority of the population and substantially contributes to their GDP..$^{41}$ When it comes to Ethiopia, Agriculture is the backbone of the country's economy since it holds 50\% of the entire GDP and $85 \%$ of the total employment in the country. ${ }^{42}$ This indicates that the sector requires due attention, especially the farmers, more than any other thing.

On the other side, it is held that IPRs' enables to strengthen the inventive capacity of local industries of developing countries. 43 With this kind of only one-sided view many developing countries, including Ethiopia, tend to justify the adoption of plant variety protection legislation. But the introduction of PBRs' in developing countries without strong local seed industry results in the domination of the seed trade by developed countries' transnational seed companies. In this context, it is the giant transnational corporations that would be the most profitable over local industries.44 In reality, PBRs' are unlikely to contribute for the enhancement of local research capacity of developing countries. For instance, foreign industries held $91 \%$ of the application for

${ }^{36}$ Dwijen Rangnekar (2001). Access to genetic resources, gene-based inventions and agriculture. Study Paper 3a, Commission on Intellectual Property Rights, p. 9.

37 Philippe Cullet (2001). Supra note 1, p. 109.

${ }^{8} \mathrm{Id}$ at pp. 109-110.

39 Id at p. 106.

$4^{40}$ Regassa Feyissa (2006). Farmers' rights in Ethiopia: A case study. Background Study 5, FNI Report 7/2006, The Farmers Rights Project, p.1.

${ }^{41}$ Philippe Cullet (2003). Supra note 4, p. 8

42 Regassa Feyissa (2006). Supra note 40, p. 1.

43 Anitha Ramanna (2002). Policy implications of India's patent reforms: Patent applications in the post1995 era. Economic \& Political Weekly, 37(21), 2065, pp. 2070-73.

44 David Godden (1984). Plant Breeders Rights and International Agricultural Research. Food Policy, 9(3), 206, p. 213. 
PBRs' in Kenya between 1997 and 1999.45 It seems that plant variety protection in developing countries is more about the interests of Western private breeders than about local farmers and breeders.

The other argument for the adoption of plant variety protection holds that the promotion of Agro-biotechnology helps to realize food security. ${ }^{6}$ The argument is that granting rights to private breeders leads to the development of better varieties that in turn increase food productivity. Privatization of the agricultural sector, however, raises serious concern about the degree to which private companies focus on Southern food priorities and the affordability of their research outputs to the local community. ${ }^{47}$ The best alternative for developing countries seems to be advancing public research on agriculture and promotion of farmers' traditional knowledge and farmers' varieties instead of relying on private breeders.

Studies indicate that research by public institutions that concentrate on staple food plants plays a key role in realizing national goals such as food security in developing countries. 48 Ethiopia, for instance, relies mostly on state-funded public institutions for plant variety deve1opment. 49 Contrary to this, private breeders focus on consumer foods instead of food security issues to maximize their profits. $5^{\circ}$ Owing to the difference in the motives of commercial and public agricultural institutions of developing countries, the propertisation of technologies and germplasm by private industries threatens public policy to realize national goals. For instance, the introduction of plant variety protection in Kenya and Zimbabwe did not bring investment in new food plants.51 Therefore, economic policies and agreements such as the TRIPS should not be implemented in a manner detrimental to the realization of human rights, which includes the right to food. $5^{2}$

It is doubtful whether modern biotechnology can bring food security in developing countries, especially, given the reluctance of commercial seed industries to focus on the priorities of developing countries.53 Food insecurity in developing countries is associated with the meager attention given to staple food production.54 It is worth mentioning, at this juncture, the impact of

45 Genetic Resource Action International (GRAIN) (1999). Plant variety protection to feed Africa? Rhetoric versus reality, p. 3 [Available at http://www.grain.org/article/entries/13-plant-varietv-protection-to-feedafrica-rhetoric-versus-reality] [Accessed on 20 September 2012].

${ }^{46}$ N. Borlaug. (1997). Feeding a world of 10 billion people: The miracle ahead. Plant Tissue Culture and Biotechnology, V. 3, 119-127 cited in Jonathan Robinson. (1999). Supra note 2, p. 72.

47 Julian M. Alston et al. (1998). Financing agricultural research: International investment patterns and policy perspectives. World Development, 26(6), 1057, pp. 1066-67; and Michael Blakeney (2007). Supra note 5 , p. $4 \mathrm{l} 1$.

${ }^{48}$ Srividhya Ragavan (2005). To sow or not to sow. Dilemmas in creating new rights in food. University of Oklahoma, p. 10 [Available at http://papers.ssrn.com/sol3/papers.cfm?abstract id=79l 666] [Accessed on 5 September 2012].

49 Regassa Feyissa (2006). Supra note 40, p. 10.

${ }^{50}$ Srividhya Ragavan (2005). Supra note 48, p. 10.

${ }^{51}$ Philippe Cullet (2001). Supra note 1, pp. 106-07, and David Godden (1984). Supra note 44, p. 210.

$5^{2}$ United Nations Sub-Commission on Human Rights (2001). Intellectual property and human rights, Resolution 2001/21, UN Doc. E/CN.4/Sub.2/RES/200l/21, UN, par. 3 \&5.

53 Philippe Cullet (2003). Supra note 4, p. 5.

54 Food and Agriculture Organization (FAO) (2000). The state of food and agriculture. Agricultural and Development Economics Working Papers, Version 32, FAO, pp. 216-18 [Available at http://www.fao.ore/docrep/x4400e/x4400eoo.htm] [Accessed on 1 September 2012]. 
the Green Revolution as experienced in Asia. Though the revolution has been associated with increased yield, it has resulted in increased seed prices, diminished farmers' ability to save seed, failed to alleviate hunger, and resulted in loss of biodiversity.55 Rather than concentrating on increasing yield alone; therefore, it is pressing to distribute existing food supplies, consolidate farmers' control over their resources and preserving natural resources. Particularly, strengthening farmers' rights is a key factor to realizing food security in Ethiopia. ${ }^{6}$ The loss of biodiversity as a result of gradual displacement of local varieties is also a serious concern. The ongoing biodiversity erosion is a compelling reason to strengthen local farmers. 57

In addition, monopoly rights also tend to commercialize agricultural inputs which, in effect, raise seed prices and renders farmers dependent on private seeds and agro-chemicals. The fact that the yield from farm saved seeds tend to drop in subsequent years causes farmers to yearly buy new seeds though they are not technically compelled so to do..$^{8}$ It is, therefore, not wise to adopt monopoly rights, particularly PBRs', in the agricultural sector of Ethiopia. The wider socioeconomic significance of agriculture for the country and its predominant reliance on farmers' varieties are compelling reason to strengthen farmers' rights. The following section deals with farmers' rights in Ethiopia.

\section{Farmers' rights in Ethiopia}

As discussed in the above sections, a number of ethical and socioeconomic reasons militate against the adoption of PBRs' in developing countries, particularly in sub-Saharan Africa. In any case, though, countries that prefer to adopt PBRs' should also accord adequate protection for their farmers. Farmers' right is a broad concept that includes the right to protection of their traditional knowledge, the right to share benefits from the utilization of their resources, the right to participate in decision making. In addition, it also includes farmers' privilege to use and exchange farm saved seeds.59 Protection of traditional knowledge consists of offering ownership status to farmers with the right to act against misappropriation and to decide over the use of their knowledge and related resources. Measures to ensure equitable benefit sharing would mandate the development of direct or indirect benefit sharing schemes in which monetary and/or nonmonetary benefits would be shared directly or indirectly between the owners (farmers) and users of the genetic resource based on prior informed consent and mutually agreed terms. Any legislation for the protection of plant varieties must incorporate these rights in a comprehensive manner.

When it comes to Ethiopia, even if the PBRs' proclamation recognizes farmers' contribution in its preamble, ${ }^{60}$ it does not provide for the details about how framers can be awarded and their rights be protected. The proclamation contains a single provision on the rights of farmers to freely use and exchange farm saved seed. ${ }^{61}$ This provision is more about the

\footnotetext{
55 Philippe Cullet (2001). Supra note 1, pp. 107-09.

${ }^{6}$ Regassa Feyissa (2006). Supra note 40, p. 17; Philippe Cullet. (2001). Supra note 1, p. 109; and Philippe Cullet. (2003). Supra note 4, p. 5 .

57 Philippe Cullet (2001). Supra note 1, p. 111; and Regassa Feyissa (2006). Supra note 40, p. 17.

58 Philippe Cullet (2001). Supra note 1, pp. 109-110.

$59 \mathrm{FAO}$ (2001). International treaty on plant genetic resources for food and agriculture. Art. 9(2)(3)

6o Plant Breeders' Rights Proclamation (2006). Supra note 21, preamble, par. 4.

${ }^{61}$ Id at Art. 28.
} 
conditions under which farmers are to be allowed to use protected varieties ${ }^{62}$ than to provide for comprehensive farmers' rights. In deed the preamble of the proclamation, unlike the OAU model law, eschews the necessity to award farmers despite recognizing their contributions. ${ }^{63}$ There must be a fair recognition of farmers' rights since farmers varieties is the predominant feature of the Ethiopian agriculture. To strike a balance between farmers and breeders' rights, intellectual property rights should also be given to farmers as well. Particularly, farmers, varieties should be certified provided that they exhibit specified characteristics in a given community though they are not distinct, stable and homogenous. This entitles farmers with exclusive rights in respect of the exploitation of their varieties. ${ }^{64}$

Ethiopia had adopted a benefit sharing legislation with the view to equitable sharing of benefits arising out of the utilization of genetic resources. Accordingly, farmers are entitled with $50 \%$ of the benefits obtained from the exploitation of genetic resources. ${ }^{65}$ Central to the benefitsharing scheme is the dichotomy between beneficiaries and non-beneficiaries of property rights. In a situation where private breeders are granted with exclusive rights and farmers' varieties remain in the public domain, the benefit-sharing scheme is meant only to compensate the farmers' deprivation of property rights. ${ }^{66}$ The existing farmers' rights such as entitlement in benefit sharing that fall short of intellectual property rights are in adequate to protecting farmers.

\section{Conclusion}

The introduction of IPRs in agro-biotechnology is held to motivate private breeders to invest in improved varieties and enhance agricultural development in addition to boosting domestic research capacity. In this connection, Ethiopia has adopted PBRs' proclamation which gives monopoly rights for private breeders. Conversely, meager attention is given for farmers rights. While private breeders have IPRs, farmers' knowledge and varieties remain in the public domain and is easily appropriated subject to payment of compensation.

Not only is the idea of invention on products of nature questionable but also IPRs does not fit with agricultural system. The agricultural system relies on farmers' varieties and free exchange of seeds. The adoption of PVP in developing countries negatively affects developing countries and their farmers. Particularly, it limits the capacity of developing countries to meet national goals and exposes farmers to depend on expensive commercial seeds. It also leads to the erosion of agro-biodiversity.

Given the fact that agriculture is the backbone of developing countries it is imperative to strengthen farmers, rights. It is not appropriate to introduce monopoly rights in plant varieties. If not, farmers should also be given intellectual property rights parallel with private breeders.

\footnotetext{
62 Regassa Feyissa (2006). Supra note 40, pp. 6-7.

${ }^{63}$ African Model Legislation for the Protection of the Rights of Local Communities, Farmers and Breeders, and for the Regulation of Access to Biological Resources (2000). Supra note 3, preamble, par. 4 \& Art. 24.

${ }^{64}$ Regassa Feyissa (2006). Supra note 40, pp. 3, 15 \& 24-5; and African Model Legislation for the Protection of the Rights of Local Communities, Farmers and Breeders, and for the Regulation of Access to Biological Resources (2000). Supra note 3, Art. 25(2).

65 Access to Genetic Resources and Community Knowledge, and Community Rights Proclamation (2006), Proclamation No. 482 /2006, Federal Negarit Gazette, $13^{\text {th }}$ Year, No. 13, Addis Ababa, Ethiopia, Art. 9(2).

66 Philippe Cullet (2001). Supra note 1, pp. 105-06.
} 
T. A. Degu - A Critical Examination of Breeders' Monopoly Rights to the Detriment of ...

\section{Acknowledgements}

This research did not receive any specific grant from funding agencies in the public commercial, or not-for-profit sectors.

The author declares no competing interests.

\section{References}

\section{Primary references}

Access to Genetic Resources and Community Knowledge, and Community Rights Proclamation (2006), Proclamation No. 482/2006, Federal Negarit Gazette, 13 ${ }^{\text {th }}$ Year, No. 13, Addis Ababa, Ethiopia.

African Model Legislation for the Protection of the Rights of Local Communities, Farmers and Breeders, and for the Regulation of Access to Biological Resources (2000), OAU, Algeria.

Agreement on Trade-Related Aspects of Intellectual Property Rights (TRIPS), (1994), Marrakesh Agreement Establishing the World Trade Organization, Annex 1C, 1869 U.N.T.S. 299, 33 I.L.M., 1197, WTO.

Convention on Biological Diversity (1992). UN Doc. 1760 UNTS 79; 31 ILM 818, UN Earth Summit, Rio de Janeiro.

Food and Agricultural Organization (FAO) (1983). International undertaking for plant genetic resource, Resolution 8/83, Report of the Conference of FAO, $22^{\text {nd }}$ Sess., Doc. C83/REP, FAO.

Food and Agricultural Organization (FAO) (1989). Agreed interpretation of the international undertaking. Resolution 4/89, Report of the Conference of FAO, $25^{\text {th }}$ Sess., Doc. C89/REP, FAO.

International Convention for the Protection of New Varieties of Plants (UPOV) (1978). Paris 2 December 196, as Revised at Geneva on November 10, 1972, and on October 23, 1978, UPOV Doc.

International Convention for the Protection of New Varieties of Plants (UPOV) (1978). Paris 2 December 196, as Revised at Geneva on 19 March 1991, UPOV Doc. 221(E), 1996.

Plant Breeders' Rights Proclamation (2006). Proclamation No. 481/2006, Federal Negarit Gazette, l2 ${ }^{\text {th }}$ Year No. 12, Addis Ababa, Ethiopia.

Seed Proclamation (2000), Proclamation No. 206/200o, Federal Negarit Gazette, $6^{\text {th }}$ Year, No. 36, Addis Ababa, Ethiopia.

The Protection of Plant Varieties and Farmers' Rights Act (2001), No. 53/2001, Gazette of India, Extraordinary Part II-Section 1, Ministry of Law, Justice and Company Affairs, India.

United Nations Sub-Commission on Human Rights (2001). Intellectual property and human rights, Resolution 2001/21, UN Doc. E/CN.4/Sub.2/RES/2001/21, UN.

\section{Secondary references}

Alston, J. M. et al. (1998). Financing agricultural research: International investment patterns and policy perspectives. World Development, 26(6), 1057-1071.

Blakeney, M. (2007). Plant variety protection, international agricultural research, and exchange of germplasm: Legal aspects of sui generis and patent regimes. In A. Krattiger et al. (Eds.), Intellectual property management in health and agricultural innovation: A handbook of best practices. MIHR, Oxford. 
Chaturvedi, S. (2002). Agricultural biotechnology and new trends in IPRs regime: Challenges before developing countries. Economic \& Political Weekly, 37(13), 1212-1222.

Cullet, P. (2001). Plant variety protection in Africa: Towards compliance with the TRIPS Agreement. Journal of African Law, 45(1), 97-122.

Cullet, P. (2003). Food security and intellectual property rights in developing countries. IELRC Working paper 2003-3, International Environmental Law Research Center, Geneva, p. 8.

IELRC Working paper 2003-3, International Environmental Law Research Center, Geneva.

Feyissa, R. (2006). Farmers rights in Ethiopia. A case study. Background Study 5, FNI Report 7/2006, Farmers Rights Project.

Food and Agriculture Organization (FAO) (2000). The state of food and agriculture. Agricultural and Development Economics Working Papers, Version 32, FAO [Available at http://www.fao.ore/docrep/x4400e/x4400eoo.htm].

Genetic Resource Action International (GRAIN) (1999). Plant variety protection to feed Africa? Rhetoric versus reality [Available at http://www.grain.org/article/entries/13-p1ant-variety-protectionto-feed-africa-rhetoric-versus-reality].

Godden, D. (1984). Plant breeders' rights and international agricultural research. Food Policy, 9(3), 206218.

Hamilton, N. D. (2001). Legal issues shaping society's acceptance of biotechnology and genetically modified organisms. Drake Journal of Agricultural Law, 6(1), 81-117.

Juma, C. (1999). Intellectual property rights and globalization. Implications for developing countries. Science, Technology and Innovation Discussion Paper No. 4, Center for International Development, Harvard University, Cambridge.

Leskien, D., \& Flitner, M. (1997). Intellectual property rights and plant genetic resources: Options for a sui generis system. Issues in Genetic Resources No. 6, International Plant Genetic Resources Institute, Italy.

Pottage, A., \& Sherman, B. (2007). Organisms and manufactures: On the history of plant inventions. Melbourne University Law Review, 31(2), 539-568.

Ragavan, S. (2005). To sow or not to sow. Dilemmas in creating new rights in food. University of Oklahoma [Available at http://papers.ssrn.com/sol3/papers.cfm?abstract id=791666].

Ramanna, A. (2002). Policy implications of India's patent reforms: Patent applications in the post-1995 era. Economic \& Political Weekly, 37(21), 2065-2075.

Rangnekar, D. (2001). Access to genetic resources, gene-based inventions and agriculture. Study Paper 3a, Commission on Intellectual Property Rights.

Robinson, J. (1999). Ethics and transgenic crops: A review. Electronic Journal of Biotechnology, 2(2), 7181.

Singh, H. (2007). Plant variety protection and food security: Lesson for developing countries. Journal of Intellectual Property Rights, 12(4), 391-399.

Thorpe, P. (2002). Study on the implementation of the TRIPS Agreement by developing countries. Study Paper 7, Commission on Intellectual Property Rights.

Tripp, R. et al. (2007). Plant variety protection in developing countries: A report from the field. Food Policy, 32(3), 354-371. 
T. A. Degu - A Critical Examination of Breeders' Monopoly Rights to the Detriment of ...

C O A $\mathbf{s}$ 